\title{
Occurrence and Distribution of Ergot and Estimates of Seed Loss in Kentucky Bluegrass Grown for Seed in Central Oregon
}

\author{
Stephen C. Alderman, Plant Pathologist, USDA-ARS National Forage Seed Production Research Center, Corval- \\ lis, OR 97331; Dale D. Coats, Research Assistant, and Fred J. Crowe, Associate Professor, Department of Botany \\ and Plant Pathology, Oregon State University; and Marvin D. Butler, Extension Agronomist, Central Oregon Agri- \\ cultural Research Center, Madras 97741
}

\begin{abstract}
Alderman, S. C., Coats, D. D., Crowe, F. J., and Butler, M. D. 1998. Occurrence and distribution of ergot and estimates of seed loss in Kentucky bluegrass grown for seed in central Oregon. Plant Dis. 82:89-93.

In 1991 to 1993, ergot was detected in 36, 44, and 62\%, respectively, of fields of Kentucky bluegrass grown for seed in central Oregon. Relatively few fields (2 to 13\%) had a high (more than 20 sclerotia/gm seed) level of ergot. Ergot severity (percent sclerotia by weight) in 1991 to 1993 was estimated at $0.85,0.07$, and $0.34 \%$, respectively. Percent seed replaced by ergot in 1991 to 1993 was estimated at $0.22,0.02$, and 0.08 , respectively. Recleaning of seed to reduce ergot contamination and to meet purity standards resulted in a $7.8 \%$ reduction in marketable seed weight. Estimated value of seed replaced by ergot in 1991, 1992, and 1993 , was $\$ 75,625$, $\$ 4,758$, and $\$ 17,076$, respectively. Estimated value of seed lost during recleaning in 1991, 1992, and 1993 , was $\$ 37,669, \$ 8,171$, and $\$ 21,964$, respectively. Weed grasses supporting ergot at the time of harvest of Kentucky bluegrass were species of Bromus, Secale, Festuca, and Poa. However, very few seed heads of weed grasses were infected, and they appeared to contribute little to ergot development in central Oregon. Most infested fields (with more than one sclerotium/gm seed prior to recleaning) or weed grass sites with ergot were located in the southern range of the area of study.
\end{abstract}

Additional keywords: Claviceps purpurea, Poa pratensis, yield loss

Ergot, caused by Claviceps purpurea (Fr.:Fr.) Tul., is an important floral disease of Kentucky bluegrass grown for seed in Oregon (1,2,3). Ergot is characterized, in the early stage of disease, by a syrupy conidia-laden "honeydew" that oozes from infected ovaries, and in the late stage of infection as an elongated, purplish-black sclerotium that extends beyond the lemma and palea of infected florets. Yield loss from ergot can occur through seed replacement, reduced seed production in infected spikelet $(15,17)$, lower seed weight $(4,8,12,13)$, lower seed vigor (11), and loss of healthy seed during recleaning to remove ergot (3).

Roughly 6,000 ha of Kentucky bluegrass are grown for seed in northeastern, central, or north-central Oregon (22). About twothirds of the production occurs in Jefferson county, located in central Oregon. Previous surveys $(1,2)$ established the occurrence of ergot in western, central, and eastern Ore-

Corresponding author: Stephen C. Alderman

E-mail: aldermas@ucs.orst.edu

Accepted for publication 3 October 1997.

Publication no. D-1997-1118-02R

This article is in the public domain and not copyrightable. It may be freely reprinted with customary crediting of the source. The American Phytopathological Society, 1998. gon. A study of ergot in eastern Oregon (3) suggested differential susceptibility among cultivars of Kentucky bluegrass, and that much of the economic impact of ergot was due to seed loss during seed cleaning to remove sclerotia. However, the value of seed lost was not determined.

Weed grasses have been documented as important sources of inoculum for ergot in cereal production $(9,10,16)$. Ergot has been reported on grasses in rangelands in central Oregon, although quantitative data are lacking (18). The severity of ergot among weed grasses in the area of Kentucky bluegrass seed production in central Oregon and the potential contribution of inoculum from this source is unknown.

In a previous report (2), ergot samples submitted to the Oregon State University (OSU) seed laboratory (seed lab) were determined to provide a convenient means of monitoring ergot incidence in Kentucky bluegrass seed production. It is not established, however, if the samples could be used to estimate ergot severity.

The objectives of this study were to (i) determine the occurrence and severity of ergot, based on field and seed lab samples from Kentucky bluegrass fields grown for seed in central Oregon; (ii) map the distribution of infested fields; (iii) determine the occurrence of ergot among weed grasses in the seed production area; and (iv) estimate the cost of seed loss due to ergot.

\section{MATERIALS AND METHODS}

Preharvest assessment: field samples. Kentucky bluegrass fields were selected at random from a listing of all fields certified by the OSU Seed Certification Office. During 1991, 148 fields were sampled by arbitrarily collecting a panicle every few steps while walking along each of four transects (100 panicles/transect) in a diamond-shaped pattern in each field. All fields were sampled within one week of cutting. Samples were placed in paper bags and air-dried. For each sample, the number of panicles with ergot, and the number of ergot per panicle were recorded. All samples were examined within 2 to 3 weeks of collection.

Postharvest assessment: combine samples. Seed samples were taken following harvest but prior to seed cleaning. Samples were drawn with a grain probe from storage bins until 0.5 to $1.0 \mathrm{~kg}$ seed was obtained. Samples were cleaned, subsampled, and assessed for ergot as previously described (3). For each sample, field location, number of hectares, and cultivar were obtained from records of the OSU seed lab and the Office of Seed Certification at OSU. The OSU seed lab is an official seed testing laboratory, responsible for testing grass and other seeds for germination, purity, or other tests that may be required for seed certification. Production data were obtained from previously published reports $(19,20,21)$.

Percent sclerotia by count (seed replaced by sclerotia) per $\mathrm{g}$ seed was determined by dividing the number of sclerotia in a sample by the number of seed and sclerotia in the sample, then multiplying by 100 . The number of seed present in a $1 \mathrm{~g}$ mixture of seed and sclerotia was determined by dividing the weight of the sclerotia by the average weight of a Kentucky bluegrass seed $\left(3.263 \times 10^{-4}\right)$, then subtracting this from 3065 (average number of seed in a 1g sample). The relationship between number of sclerotia per gram of seed and percent seed replaced by sclerotia was evaluated using polynomial regression analysis.

Postharvest assessment: seed lab samples. During testing of seed purity, the OSU seed lab records pieces of ergot found in the sample. Seed purity data, including ergot counts, from 1991 to 1993 were obtained from archived records of the seed 
lab. Twenty-five Kentucky bluegrass seed samples, identified from seed lab records as containing ergot, were obtained from the seed lab. The number of sclerotia and sclerotial pieces were counted and pieces combined to estimate total whole sclerotia. The relationship between pieces of ergot and estimated whole ergot was determined using linear regression analysis. This relationship was used to convert ergot counts of the seed lab from number of pieces to whole sclerotia.

The relationship between counts of ergot (estimated whole sclerotia) in seed lab

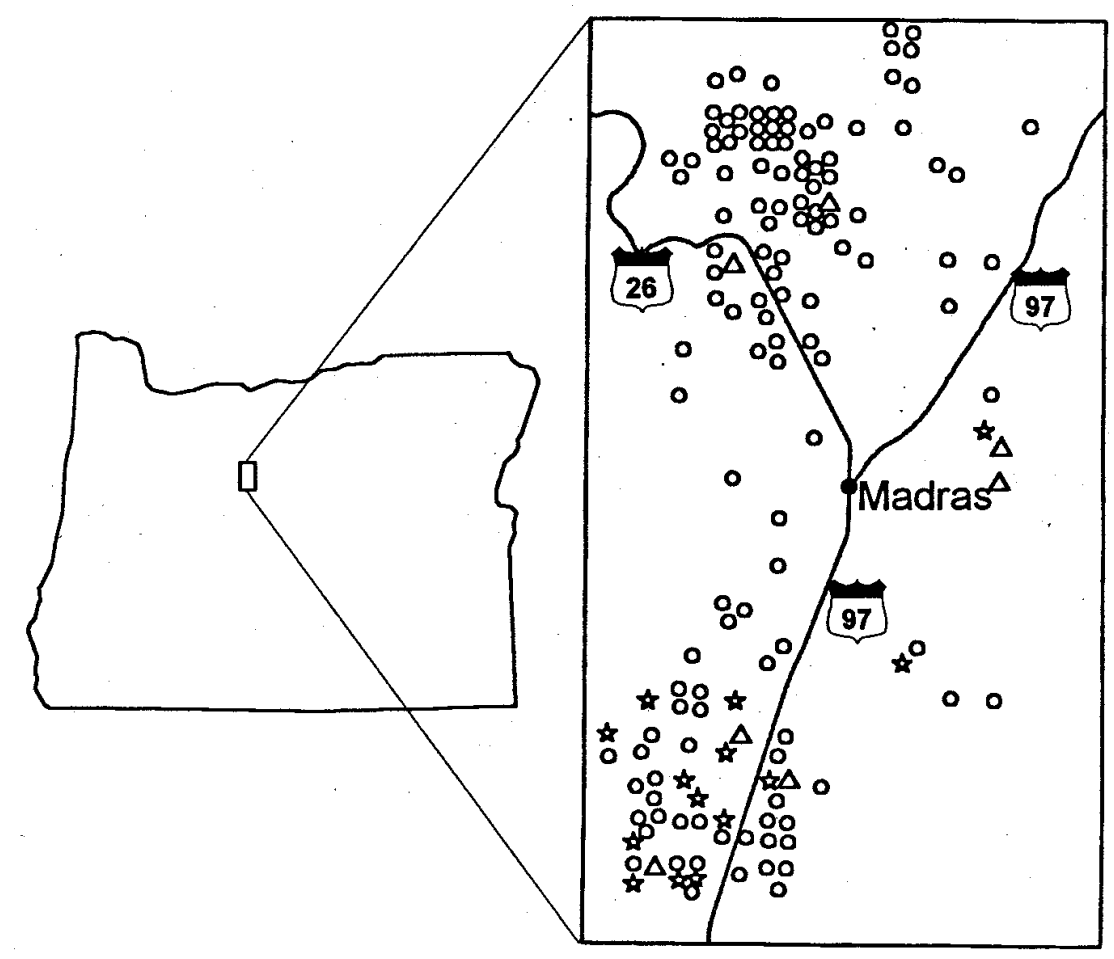

Fig. 1. Distribution of ergot among Kentucky bluegrass fields grown for seed in central Oregon during 1991, as determined from preharvest field samples. Fields where $0,<1$, or $\geq 1$ sclerotium/g seed were detected are represented by open circles, triangles, or stars, respectively.

samples and counts from combine samples was evaluated using linear regression analysis. The analysis included only those seed lab and corresponding combine samples that were traced to the same fields. In a few cases, where multiple samples were submitted to the seed lab, the ergot counts were averaged. Additional data concerning the occurrence of ergot among seed lab samples in 1994 and 1995 were obtained from records of the seed lab.

Weed grass survey. Ergot among weed grasses in 1991 was assessed in July, which coincided with commercial harvest of Kentucky bluegrass seed. Township-rangesections for townships $9,10,11$, and 12 in ranges 13 and 14, which included nearly all of the production area, were assigned a number. Computer-generated random numbers were used to randomly select sections. A total of 127 sections were selected. Townships and ranges are public survey units. Each township-range designation includes 36 sections, each about 1.6 $\mathrm{km}^{2}$ in area. Within each section, a site was arbitrarily chosen, generally between a roadway and a field edge. At each site, all seed heads within a two-square-meter area were collected and placed in paper bags. Grass species or genera and ergot incidence for each grass were recorded. Identity of grass species was verified by the OSU herbarium.

Estimation of seed loss. Prices of Kentucky bluegrass seed for 1991 to 1993 were obtained from the OSU Economic Information Office. Price of Kentucky bluegrass seed per hundredweight during 1991, 1992, and 1993 were $\$ 69.00, \$ 90.50$, and $\$ 94.6$,
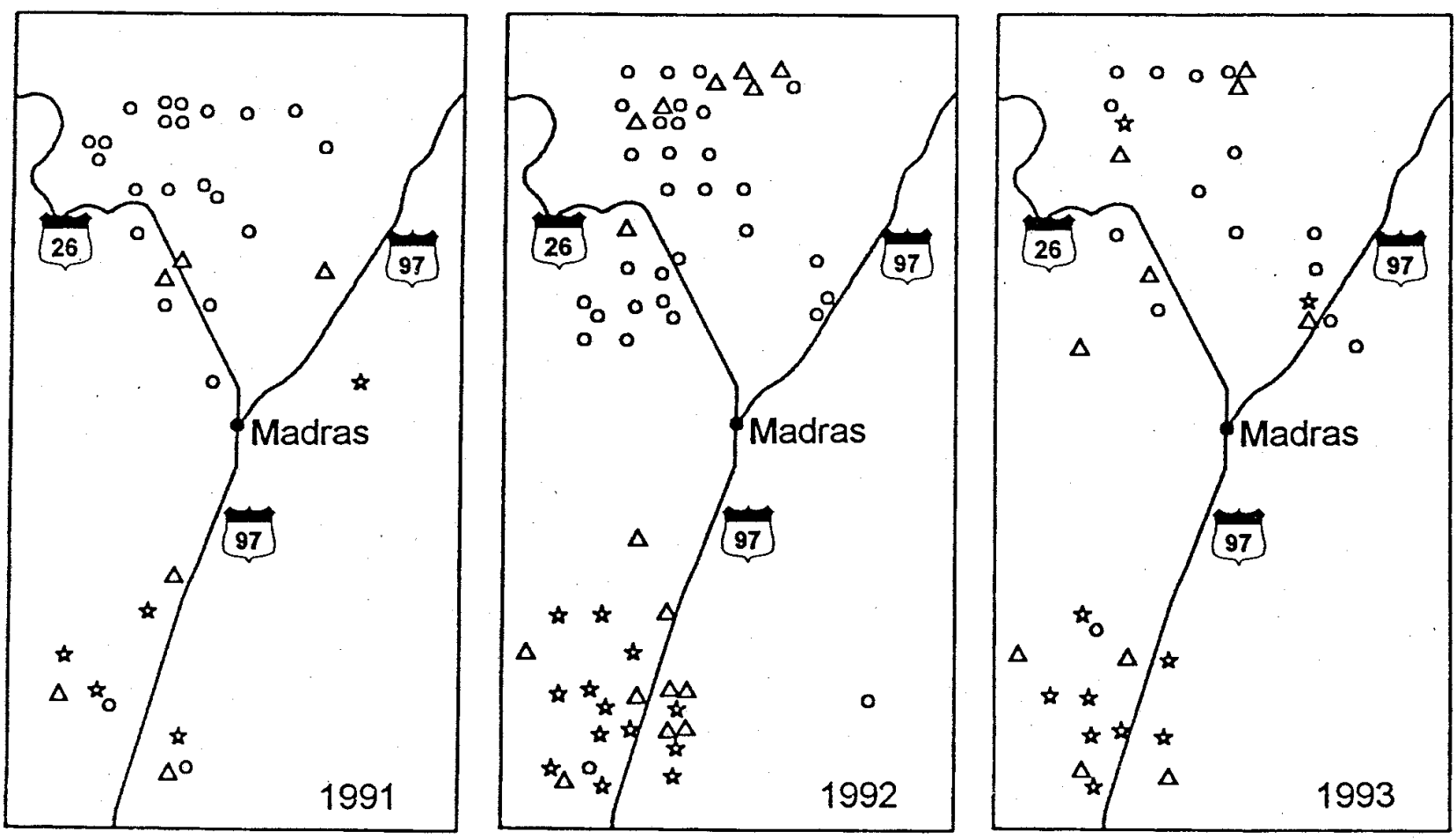

Fig. 2. Distribution of ergot among Kentucky bluegrass fields in central Oregon during 1991, 1992, and 1993, as determined from postharvest seed samples. Fields where $0,<1$, or $\geq 1$ sclerotium/g seed were detected are represented by open circles, triangles, or stars, respectively. 
respectively. Estimates of seed loss (seed replaced by ergot) were multiplied by price to obtain an estimated value of lost seed. Estimation of seed lost for total Kentucky bluegrass production was determined by the relationship (proportion of seed lost in fields sampled $\times$ seed weight of total seed production).

\section{RESULTS}

Occurrence and distribution of ergot. Ergot was detected in 20 out of 148 fields sampled in 1991. Fifteen of the 20 fields were located in southern Jefferson Co. (Fig. 1). A similar distribution of infested fields was mapped from results of combine samples from 1991 to 1993 (Fig. 2).

In 1991-1993, ergot was not detected in 38 to $64 \%$ of the fields, based on combine samples (Table 1). In 18 to $34 \%$ of the fields, ergot was detected at trace levels (fewer than one sclerotium/g seed). Relatively few fields ( 2.3 to $12.8 \%$ ) had more than $20 \mathrm{sclerotia} / \mathrm{g}$ seed. The highest level of ergot observed was 137 sclerotia/g (20\% ergot by weight) from a field of cv. Chateau in 1991.

Mean ( \pm standard deviation) weight per sclerotium of C. purpurea in 1991 to 1993 was $1.46 \pm 1.49,1.01 \pm 0.38$, and $0.86 \pm$ $0.22 \mathrm{mg}$, respectively. One sclerotium per gram of seed equated to $0.03 \%$ replaced seed (Fig. 3).

Percent fields with ergot in 1991 to 1993, based on seed lab and combine samples, were similar (Table 2). In samples from 1991 to 1993 , ergot was found in 7 to $11 \%$ of seed lab samples but not in corresponding combine samples from the same fields. Similarly, ergot was found in 3 to $4 \%$ of combine samples but not in seed lab samples. The deviations between seed lab and combine samples occurred at ergot levels of 1 to 4 sclerotia/g seed.

Table 1. Percentage of fields of Kentucky bluegrass among classes of ergot severity (sclerotia per gram of seed) and percentages of fields recleaned

\begin{tabular}{lcccccc}
\hline & & \multicolumn{4}{c}{$\begin{array}{c}\text { \% fields in each class } \mathbf{a}^{\mathbf{2}} \\
\text { (sclerotia per gram of seed) }\end{array}$} & \\
\cline { 2 - 6 } Year & $\begin{array}{c}\text { No. of fields } \\
\text { assessed }\end{array}$ & $\mathbf{0}$ & $>\mathbf{0}$ to 0.9 & $\mathbf{1 . 0}$ to 19.9 & $\geq \mathbf{2 0}$ & Fields recleaned (\%) \\
\hline 1991 & 39 & 64.1 & 18.0 & 5.1 & 12.8 & 15.3 \\
1992 & 87 & 56.3 & 24.1 & 17.2 & 2.3 & 6.9 \\
1993 & 68 & 38.2 & 33.8 & 25.0 & 2.9 & 8.8 \\
\hline
\end{tabular}

a Percent determined from analysis of a 10-g subsample from each combine sample from each field.

Table 2. Percentage of samples from the Oregon State University seed laboratory (seed lab) and combine samples with ergot in 1991 to 1993

\begin{tabular}{lccccc}
\hline & \multicolumn{2}{c}{ \% samples with ergot $^{\mathbf{a}}$} & & \multicolumn{2}{c}{ \% deviation } \\
\cline { 2 - 3 } \cline { 5 - 6 } Year & Seed lab & Combine & & Seed lab $^{\mathbf{b}}$ & Combine $^{\mathbf{c}}$ \\
\hline 1991 & 34 & 37 & & 8.6 & 11.4 \\
1992 & 56 & 47 & & 11.3 & 2.8 \\
1993 & 59 & 61 & & 7.1 & 10.7 \\
\hline
\end{tabular}

${ }^{a}$ Based on fields where both seed lab and combine samples were available.

b Percent samples in which ergot was detected in seed lab but not combine samples.

${ }^{c}$ Percent samples in which ergot was detected in combine but not seed lab samples. these appeared to be restricted to several highly susceptible cultivars. Similar results were reported during this same time period from northeastern Oregon (3). Cultivars resistant to ergot have been released $(7,14)$ and may play a role in reducing the impact of ergot in production of Kentucky bluegrass seed.

A greater incidence of ergot occurred in southern Jefferson County than in northern Jefferson County. This distribution was independent of cultivar because in many cases the same cultivars free of ergot in the

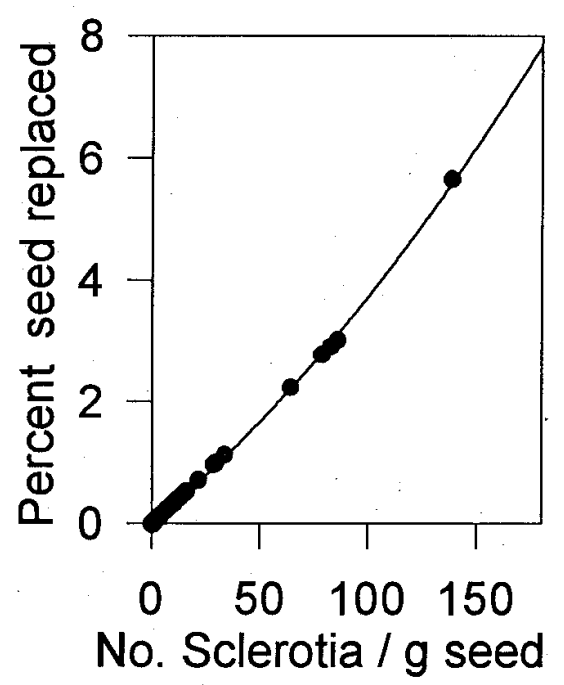

Fig. 3. Relationship between number of sclerotia of Claviceps purpurea per gram of Kentucky bluegrass seed and percentage of seed replaced by sclerotia. The second order polynomial regression equation is $y=5.55 \times 10^{-3}+$ $0.03 x+7.74 \times 10^{-5} x^{2}, r^{2}=0.99$

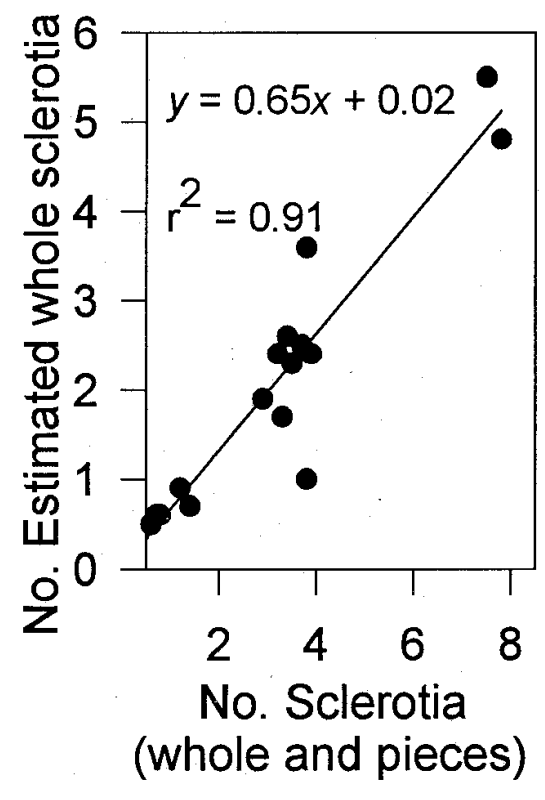

Fig. 4. Relationship between number of sclerotia (whole and pieces) among seed samples from the Oregon State University seed laboratory and number of corresponding estimated whole sclerotia. 
northern range of the county were infected in the southern range. Similarly, ergot was found among weed grasses only in the southern area. The northern area is a relatively flat area known as the Agency Plains. The southern area is characterized by gently rolling hills. It is not clear why the incidence of ergot was greater in the southern area.

Claviceps purpurea has a host range which may be as large as 200 to 400 grass species $(5,6)$. In the Willamette Valley

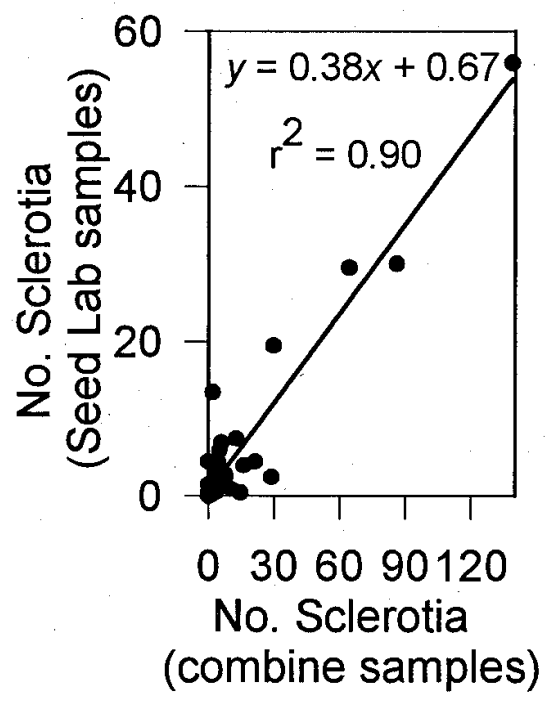

Fig. 5. Relationship between counts of Claviceps purpurea sclerotia from samples submitted to the Oregon State University seed laboratory and from combine samples obtained from the same fields during 1991 to 1993. (about 120 miles west of central Oregon and separated from it by the Cascade mountains), ergot is common among weed grasses. Relatively little ergot occurred among weed grasses in central Oregon. This may be due to the typically dry conditions east of the Cascade mountains. Irrigation is required for Kentucky bluegrass seed production in central Oregon, and moisture conditions may not be adequate to support extensive ergot production among the weed grasses. The low level of ergot occurring on weed grasses suggests that little inoculum would be available from field margins and that the primary source of inoculum is from within the fields.

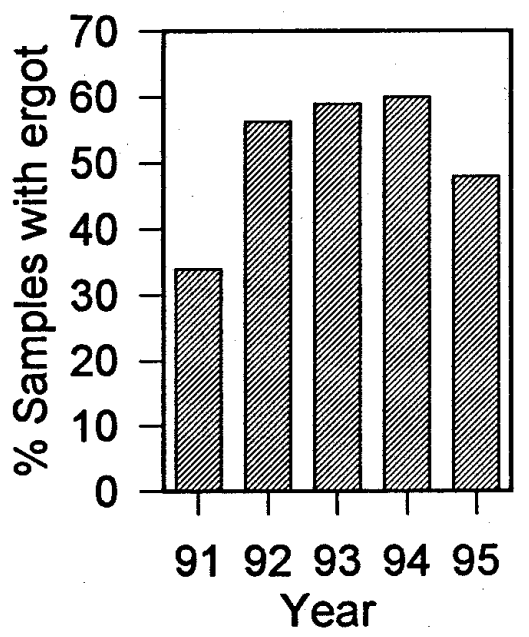

Fig. 6. Percent Kentucky bluegrass samples submitted to the Oregon State University seed laboratory containing ergot in 1991 to 1995.
The contribution of ergot developing on grasses in rangelands surrounding the Kentucky bluegrass production area is not known, although conditions are typically dry during the period of flowering and seed maturation in Kentucky bluegrass. Reports of Stur et al. (19) suggest that ergot may be widespread on giant wild rye, blue joint grass, and Nevada bluegrass, although quantitative data are lacking.

The percent of fields with ergot, based on combine and seed lab samples, was similar. As suggested previously (2), data from the OSU seed lab is a reliable and convenient source of information regarding ergot incidence. Estimation of severity can be obtained from the conversion of pieces of sclerotia observed in seed lab samples to whole sclerotia and from the relationship between combine and seed lab samples.

Ergot is considered a component of inert matter, and weight of inert matter is used in the calculation of seed purity. Ergot as a seed contaminant is of little concern unless the quantity of ergot (by weight) reduces seed purity.

In northeastern Oregon, 3 to $4 \%$ of fields were recleaned during 1991 to 1993 (3). In central Oregon, 7 to $15 \%$ of fields were recleaned, although only 2 to $12 \%$ of the fields had a high level of ergot. Recleaning in northeastern Oregon reduced seed yield by $9 \%$ and number of sclerotia by $23 \%$. In central Oregon, recleaning resulted in a loss of $8 \%$ seed and reduced ergot level by $33 \%$. Thus, number of fields recleaned and loss of seed during recleaning was similar between northeastern and central Oregon.

Table 3. Percentage of yield loss, based on sclerotium weight or direct seed replacement, in central Oregon due to ergot, and estimated cost of seed lost through replacement by ergot sclerotia or through recleaning to remove sclerotia

\begin{tabular}{cccccrr}
\hline Year & Production $(\mathbf{k g} \times \mathbf{1 , 0 0 0})$ & Seed assessed $(\mathbf{k g} \times \mathbf{1 , 0 0 0})$ & $\begin{array}{c}\text { Sclerotia } \\
(\mathbf{\%} \text { by weight })^{\mathbf{a}}\end{array}$ & $\begin{array}{c}\text { Sclerotia } \\
(\boldsymbol{\%} \text { by count }) \text { a }\end{array}$ & $\begin{array}{c}\text { Loss due to } \\
\text { seed replacement }^{\text {a }}\end{array}$ & $\begin{array}{c}\text { Loss due to } \\
\text { recleaing }^{\mathbf{a}}\end{array}$ \\
\hline 1991 & 5,762 & 370 & 0.85 & 0.22 & $\$ 75,625$ & $\$ 37,669$ \\
1992 & 3,542 & 1,032 & 0.07 & 0.02 & $\$ 4,758$ & $\$ 8,171$ \\
1993 & 3,339 & 799 & 0.24 & 0.08 & $\$ 17,076$ & $\$ 21,964$ \\
\hline
\end{tabular}

a Based on seed assessed.

Table 4. Occurrence of ergot among weed grasses in central Oregon

\begin{tabular}{|c|c|c|c|c|}
\hline Host & Number of sites ${ }^{a}$ & Total seed heads examined & Number of heads with ergot & Heads with ergot (\%) \\
\hline Alopecurus geniculatus L. & 4 & 401 & 0 & 0 \\
\hline Avena L. sp. & 8 & 251 & 0 & 0 \\
\hline Bromus secalinus L. & 55 & 6,390 & 0 & 0 \\
\hline Other Bromus L. sp. & 17 & 2,062 & 24 & 1.16 \\
\hline Dactylis glomerata L. & 3 & 127 & 0 & 0 \\
\hline Elymus L. sp. & 13 & 2192 & 11 & 0.50 \\
\hline Elytriga repens (L.) Nevski & 52 & 9,386 & 0 & 0 \\
\hline Festuca arundinacea Schreb. & 54 & 8,873 & 5 & 0.56 \\
\hline Festuca rubra L. & 6 & 2,102 & 0 & 0 \\
\hline Other Festuca L. sp. & 4 & 823 & 0 & 0 \\
\hline Hordeum jubatum L. & 5 & 823 & 0 & 0 \\
\hline Hordeum leporinum Link & 10 & 1,336 & 0 & 0 \\
\hline Lolium multiflorum Lam. & 3 & 524 & 0 & 0 \\
\hline Phalaris arundinacea $\mathrm{L}$. & 6 & 375 & 0 & 0 \\
\hline Poa L. sp. & 56 & 9,589 & 2 & 0.02 \\
\hline Triticum L. sp. & 2 & 15 & 0 & 0 \\
\hline
\end{tabular}

${ }^{\mathrm{a}}$ Number of sites out of 127 where a given species was found. 
The cost of ergot, in terms of seed replacement, was estimated at about $\$ 13,000$ to $\$ 113,000$. Ergot at levels contributing to less than $1 \%$ inert matter would have little to no impact on seed loss or increased cost due to recleaning. At levels of ergot contributing greater than $1 \%$ purity, costs associated with ergot include the value of seed replaced with ergot, value of seed lost through recleaning, the charge for recleaning, and costs of disposal of screenings. Additional seed loss may occur during harvest if honeydew is present, because the sticky exudate tends to aggregate seeds and debris and stick to machinery and equipment. The loss of Kentucky bluegrass seed during harvest when honeydew is present needs to be investigated. In addition, estimates of lost seed based on sclerotia in samples does not include seed or sclerotia lost during harvest and returned to the field. Additional studies are needed to determine the contribution of these yield loss components.

\section{ACKNOWLEDGMENTS}

We are grateful to Cenex, Full Circle, Olsen Seed, and Round Butte Seed companies for providing seed samples and corresponding field data.

\section{LITERATURE CITED}

1. Alderman, S. C. 1991. Distribution of Claviceps purpurea, Gloeotinia temulenta, and Anguina agrostis among grasses grown for seed in Oregon in 1989. J. Appl. Seed Prod. 9:44-48.

2. Alderman, S. C. 1991. Assessment of ergot and blind seed diseases of grasses in the Willamette Valley of Oregon. Plant Dis. 75:10381041.

3. Alderman, S. C., Coats, D. D., and Crowe, F. J. 1996. Impact of ergot on Kentucky bluegrass grown for seed in northeastern Oregon. Plant Dis. 80:853-855.

4. Bacon, C. W., and Luttrell, E. S. 1982. Competition between ergots of Claviceps purpurea and rye seeds for photosynthates. Phytopathology 72:1332-1336.

5. Bove, F. J. 1970. The Story of Ergot. S. Karger, Basal, Switzerland.

6. Brady, L. R. 1962. Phylogenetic distribution of parasitism by Claviceps species. Lloydia 25:1-36.

7. Brede, A. D., and Willard, W. E. 1993. Registration of "Nustar" Kentucky bluegrass. Crop Sci. 33:1414-1415.

8. Brentzel, W. E. 1947. Studies on ergot of grains and grasses. N. D. Agric. Exp. Stn. Bull. 348.

9. Bretag, T. W. 1985. Control of ergot by a selective herbicide and stubble burning. Trans. Br. Mycol. Soc. 85:341-343.

10. Bretag, T. W., and Merriman, P. R. 1981. Epidemiology and cross-infection of Claviceps purpurea. Trans. Br. Mycol. Soc. 77:211-213.

11. Chastain, T. G. 1992. Relationship of ergot to Kentucky bluegrass seed production quality. J. Appl. Seed Prod. 10:7-10.

12. Corbett, K., Dickerson, A. G., and Mantle, P. G. 1974. Metabolic studies on Claviceps purpurea during parasitic development on rye. J. Gen. Microbiol. 84:39-58.
13. Harper, F. R., and Seaman, W. L. 1980. Ergot of rye in Alberta: Estimation of yield and grade losses. Can. J. Plant Pathol. 2:222-226.

14. Jacklin, A. W., Brede, A. D., Brilman, L. A., and Funk, C. R. 1989. Registration of "Huntsville" Kentucky bluegrass. Crop Sci. 29:6

15. Kossobutzky, M. I. 1930. Ergot (Claviceps purpurea Tul.) in the Votyaks' autonomous region in the years 1926-1928. (Pamphlet issued by Votyaks Regional Plant Prot. Stut. and Scient. Soc. for the Study of the Votyaks Region. Leningrad, 1929.) Rev. Appl. Mycol. 9:103-104.

16. Mantle, P. G., and Shaw, S. 1977. A case study of the etiology of ergot disease of cereals and grasses. Plant Pathol. 26:121126.

17. Seymour, E. K., and McFarland, F. T. 1921 Loss from rye ergot. Phytopathology 11:285289.

18. Stur, E. T., Christensen, B. E., and Wong, E. 1943. Assay of ergot. J. Am. Pharm. Assoc. Sci. Ed. 32:241-244.

19. Young, W. C., III. 1991. Oregon grass and legume seed production statistics. Department of Crop and Soil Science, Oregon State University, Corvallis.

20. Young, W. C., III. 1992. Oregon grass and legume seed production statistics. Department of Crop and Soil Science, Oregon State University, Corvallis.

21. Young, W. C., III. 1993. Oregon grass and legume seed production statistics. Department of Crop and Soil Science, Oregon State University, Corvallis.

22. Young, W. C., III. 1996. Seed Production. Oregon State Univ. Ext. Serv. Crop \& Soil News/Notes 10:3-6. 